\title{
Identification of genes associated with shell color in the black-lipped pearl oyster, Pinctada margaritifera
}

\author{
Sarah Lemer ${ }^{1,2^{*}}$, Denis Saulnier ${ }^{3}$, Yannick Gueguen ${ }^{3,4}$ and Serge Planes ${ }^{1}$
}

\begin{abstract}
Background: Color polymorphism in the nacre of pteriomorphian bivalves is of great interest for the pearl culture industry. The nacreous layer of the Polynesian black-lipped pearl oyster Pinctada margaritifera exhibits a large array of color variation among individuals including reflections of blue, green, yellow and pink in all possible gradients. Although the heritability of nacre color variation patterns has been demonstrated by experimental crossing, little is known about the genes involved in these patterns. In this study, we identify a set of genes differentially expressed among extreme color phenotypes of $P$. margaritifera using a suppressive and subtractive hybridization (SSH) method comparing black phenotypes with full and half albino individuals.
\end{abstract}

Results: Out of the 358 and 346 expressed sequence tags (ESTs) obtained by conducting two SSH libraries respectively, the expression patterns of 37 genes were tested with a real-time quantitative PCR (RT-qPCR) approach by pooling five individuals of each phenotype. The expression of 11 genes was subsequently estimated for each individual in order to detect inter-individual variation. Our results suggest that the color of the nacre is partially under the influence of genes involved in the biomineralization of the calcitic layer. A few genes involved in the formation of the aragonite tablets of the nacre layer and in the biosynthesis chain of melanin also showed differential expression patterns. Finally, high variability in gene expression levels were observed within the black phenotypes.

Conclusions: Our results revealed that three main genetic processes were involved in color polymorphisms: the biomineralization of the nacreous and calcitic layers and the synthesis of pigments such as melanin, suggesting that color polymorphism takes place at different levels in the shell structure. The high variability of gene expression found within black phenotypes suggests that the present work should serve as a basis for future studies exploring more thoroughly the expression patterns of candidate genes within black phenotypes with different dominant iridescent colors.

Keywords: Differential expression, Biomineralization, Nacre, Pearl, Pigmentation, Albino

\section{Background}

Color polymorphisms of mollusk shells have fascinated humans throughout history. Color polymorphism results from a combination of multiple factors starting from inner genetic to mitigating environmental factors related to biochemistry, substrate or nutrition [1,2]. Experimental crosses have shown that shell color has a genetic

\footnotetext{
* Correspondence: sarah.lemer@gmail.com

'Laboratoire d'Excellence "CORAIL", USR 3278 CNRS-CRIOBE- EPHE, Perpignan, France, Papetoai, Moorea, French Polynesia

${ }^{2}$ Present address: Department of Organismic and Evolutionary Biology, Museum of Comparative Zoology, Harvard University, 26 Oxford Street, Cambridge, MA 02138, USA

Full list of author information is available at the end of the article
}

basis [3-5]. Most studies have reported a relatively simple genetic basis for color polymorphisms involving one or two loci with dominance [6-8], although more elaborate polymorphisms are likely to arise from complex multigenic systems $[9,10]$. Recent studies have shown that marine shellfish tend to display more complex patterns of pigmentation than freshwater shellfish [11]. Examples of complexity are mostly found on shells displaying a nacreous layer (i.e. mother of pearl) such as the gastropods in the family Haliotidae (abalone), the cephalopod family Nautlidae (chambered Nautilus), or the bivalves of the families Pteriidae, Mytilidae and Pinnidae. Because of its high industrial value, the composition and 
formation of the nacreous layer have been studied in multiple taxa at different levels of expertise: proteomics [12-21], genetics [22-26, 21], optics [27, 28], mineralogy [29] and chemistry [30-32]. The nacre is made of regular layers of aragonite tiles and is unique from its iridescence. Iridescence is usually attributed to a diffraction effect caused by the evenly grooved surface microstructure, similar to that of a diffraction grating [33, 34, 27]. The rainbow-like diffraction colors arise from surface repetition of the nacreous layers (growth lines) and are named by gemologists "orient" [29]. However, not all iridescences arise from surface regularities and the pigments present in the binding regions of the aragonite tiles and integrated in the biomineralization process also play a role in the color of the nacreous layer [29]. Therefore the process of biomineralization of the nacreous layer is of great economic interest to the pearl aquaculture industry. As a result, extensive studies have been conducted to identify proteins responsible for the nacre formation by screening proteins contained in the shell and genes specifically expressed in the calcifying tissues i.e. the mantle $[35,36]$.

A wide variety of proteins and genes have been identified and their functions in nacre formation have been partially characterized (reviewed in [35, 37-41]). Our knowledge of the "biomineralization toolkit" involved in the formation of the calcitic and aragonitic layers is expanding and we now know more about how the different shell layers are synthesized and how their production is genetically regulated [37]. Nevertheless the precise molecular mechanism controlling color polymorphism in nacre remains unexplored and is far from being understood. To address this key question we searched for specific genes displaying differential expression patterns among different shell color phenotypes of the Polynesian black-lipped pearl oyster, Pinctada margaritifera. The nacreous layer of $P$. margaritifera exhibits a large array of color variation among individuals, although the shell is usually simply referred to as black. The heritability of nacre color variation patterns in $P$. margaritifera have been demonstrated by experimental crossing and by maintaining single colored dominated lineages (CL. Ky personal communication). An interesting feature of $P$. margaritifera is the rare occurrence of albinos, 1 out of 10,000 , displaying total or partial absence of coloration. Albinos are characterized by a white shell (periostracum and calcitic layer) and a white mantle (Fig. 1a) in opposition to the common black shells (Fig. 1c). In some rare cases the mantle of albino specimens remains black (S. Planes and S. Lemer, pers. observation; [42]; Fig. 1b); supporting the multiple genetic origins of the absence of color in the shell. In the context of our study, the comparison of

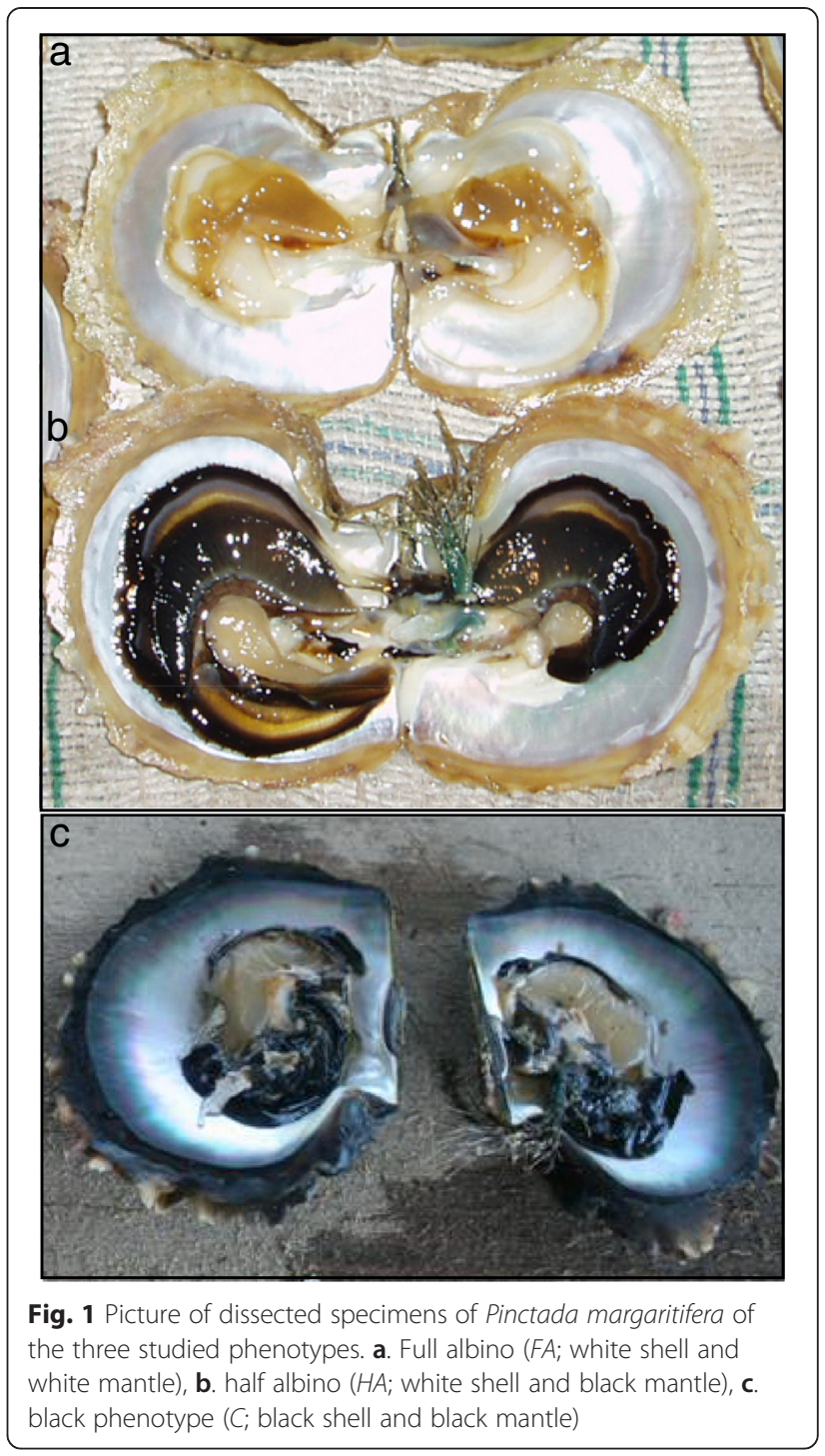

albino specimens and black specimens is an ideal method to identify the genetic processes directly linked to shell color polymorphisms.

Albinism is induced by the absence of melanin or by non-functional melanin molecules as a result of one or more mutations in genes involved in the melanin biosynthesis chain [43-49]. Melanin has been identified in many mollusk species, including cephalopods, gastropods, and bivalves [50]. In P. margaritifera, melanin is secreted in the epithelium of the median and internal fold of the mantle edge and in the pallial area [51]. The mantle edge is directly responsible for the biomineralization of the shell and more specifically of the nacre layer [21]. As a consequence, it is the chosen mantle part used by professional grafters in pearl culture manufacture to isolate grafts, that will be transplanted together with a marble in the gonads of a recipient oyster. Three proteins closely related to the tyrosinase, known to play a 
role in melanin biosynthesis, have previously been characterized in the pallial or edge region of the mantle of Pinctada fucata: OT47, Pfty1 and Pfty2 [52, 53]. The localization of these proteins suggests that they could be integrated in the shell layers including the nacre layer during the biomineralization process.

In this study, we aimed at identifying genes involved in the origin and potentially the polymorphism of color in the nacreous layer of $P$. margaritifera. We hypothesized that the variety of colors found in the nacre is a combined result of variation in expression of genes involved in the formation of the shell's microstructure and of genes involved in pigmentation. In order to test this hypothesis, we identified and compared coding genes differentially expressed between normal black specimen of pearl oysters and two types of albinos using a suppressive and subtractive hybridization method, that we then tested and validated with RT-qPCR runs. We identified genes involved in the formation of the calcitic layer, the aragonite tablets of the nacre and in the biosynthesis chain of melanin suggesting that color polymorphism takes place at different levels of the shell structure.

\section{Methods \\ Biological material}

In order to identify genes involved in the origin and potentially in the variation of shell color, mantle tissue of Pinctada margaritifera from 3 phenotypes was obtained from adult specimens of similar size and raised in the same pearl farm in the Gambier archipelago (Mangareva, French Polynesia) in 2011. The three sampled phenotypes were: the normal black phenotype of $P$. margaritifera (black shell and black mantle) referred hereafter as phenotype $C$ (Fig. 1b); the full albino phenotype (white shell and white mantle) referred hereafter as phenotype FA (Fig. 1a); the half albino phenotype (white shell and black mantle) referred hereafter as phenotype $H A$. We sampled five individuals of each phenotype. The mantle edge of each individual was dissected by a professional grafter following the method used for pearl production, in order to insure the use of the specific part of the mantle producing the calcitic and aragonite layers. Each sample was immediately preserved in RNAlater" RNA Stabilization Reagent (Qiagen, USA) transported to the laboratory and stored at $-80{ }^{\circ} \mathrm{C}$.

\section{RNA isolation and subtractive cDNA library construction} Total RNA from mantle tissue of individuals of phenotypes $C, H A$ and $F A$ was isolated using TRIzol reagent (Invitrogen) according to the manufacturer's instructions. The RNA pellet was washed with $70 \%$ ethanol and air-dried, dissolved in DEPC-treated water and stored at $-80{ }^{\circ} \mathrm{C}$.
Total RNA was purified using the RNeasy Mini Kit (Qiagen, USA).

The suppressive subtractive hybridization technique (SSH) [54] was used to characterize genes involved in the origin of shell color by comparing expression between the phenotypes $C$ and $F A$. For the forward library, cDNA from five phenotype $F A$ samples was used as tester and cDNA from five phenotype $C$ samples was used as driver, and vice versa for the reverse subtractive library. The construction of the libraries, clone sequencing, vector and adaptor trimming and differential screening using dot blot hybridization were outsourced to Rx. Bioscience Ldt (Maryland, USA). Briefly, both forward and reverse subtracted libraries were produced from 2 ng mRNA. First and second strand cDNA synthesis, RsaI endonuclease enzyme digestion, adapter ligation, hybridization, and PCR amplification were performed as described in the PCR-select cDNA subtraction kit manual (Clontech, Palo Alto, CA, USA) with modifications as described in [55] for the Mirror Orientation Selection protocol. Differentially expressed PCR products were ligated into pJetBlunt cloning vector (Fermentas) and transformed in Escherichia coli competent cells. For the differential screening by dot blotting, 1000 clones per library were randomly transferred on two nylon membranes and hybridized with $C$ and FA cDNA probes, respectively. Nylon membranes were then auto-radiographed and superimposed for identification of differentially expressed clones. Among clones showing the most intense differential signal after hybridization to cDNA probes, 960 were randomly selected for sequencing in each library.

\section{Sequence analysis}

For each library, the 960 clones were sequenced and vector trimmed by RxBioScience Ltd. (Maryland, USA). Highquality expressed sequenced tag (ESTs) ( $>100 \mathrm{bp}$ ) were assembled into clusters or identified as unique sequences and used for database searches with the BlastX and BlastN programs on the NCBI server (http://www.ncbi.nlm.nih.gov/ BLAST/) and UniProt. (http://www.uniprot.org/blast/) Search of homology was also conducted in an EST bank of Pinctada margaritifera [21]. In addition, functional annotation was performed in Blast2Go (http://www.blast2go.com/) where gene information were obtain by blasting sequences in Gene Ontology (http://www.geneontology.org/). Enriched Molecular function GO terms were then uploaded to REVIGO (Reduce + Visualize Gene Ontology http://revigo.irb.hr/) for visualization. REVIGO summarizes the long list of GO terms by removing redundant terms and grouping related terms based on semantic similarity [56]. The EST sequences used in this study have been submitted to the online database (Accession numbers: JZ845577JZ845610; JZ845790-JZ845792). 


\section{Differential expression validated by quantitative RT-PCR}

Quantitative real-time PCR (RT- $q$ PCR) was used to analyze the expression profiles of selected genes. Total RNA was extracted and reverse-transcribed $(2 \mu \mathrm{g})$ using oligo dT primers and the Superscript II enzyme (Invitrogen).

At first, the cDNA from each of the five individuals for each phenotype $(C, F A$ and $H A)$ were pooled in equal amounts (25 ng/ $\mu \mathrm{L}$ each). Quantitative RT-PCR analyses were run on the three pooled samples for all selected genes. The genes showing the most significant differential expression profile among the three phenotypes were then selected to conduct subsequent RT- $q$ PCR analysis on each individual sample separately in order to detect individual variability (Table 1 ).

Both pooled and individual RT- $q$ PCR analysis were conducted as the following: in each $25 \mu$ l reaction, $10 \mu \mathrm{l}$ cDNA (diluted 1:100 in water) was mixed with $12.5 \mu \mathrm{l}$ Brillant $^{\oplus}$ II SYBR Green Master Mix (Stratagene) and $0.2 \mu \mathrm{M}$ of each primer (primer pairs listed in Table 1). This allowed for the consistent use of standardized thermal cycling conditions performed using a Mx3000P Real-Time PCR System (Stratagene): $95{ }^{\circ} \mathrm{C}$ for $10 \mathrm{~min}$, followed by 40 cycles of $95{ }^{\circ} \mathrm{C}$ for $30 \mathrm{~s}, 60{ }^{\circ} \mathrm{C}$ for $1 \mathrm{~min}$ and $72{ }^{\circ} \mathrm{C}$ for $1 \mathrm{~min}$ which were found to give efficiencies $>90 \%$ (see below). The RT- $q$ PCR reactions were run in triplicate for the pooled analysis and in duplicate for the individual analyses. Melting curve profiles (95 to $55{ }^{\circ} \mathrm{C}$ decreasing by $1{ }^{\circ} \mathrm{C}$ every $30 \mathrm{~s}$ ) were assayed to ensure that we were looking at a single product. Each run included three positive cDNA controls also used as interplate calibrators, and three non-DNA template controls (water) for each primer pair and four housekeeping genes: RNA and export factor binding protein 1 or REF 1 [57], 18S [58], Elongation factor 1 or EF1 (EF1S: ATGCTGCCATGGTTGATATG/EF1: GTGGCCTCAGC TTTCTCAAC) and Glyceraldehyde-3-Phosphate Dehydrogenase or GAPDH (GAPDH1S: AGGCTTGATGACCACTGTCC / GAPDH1R: AGCCATTCCCGTCA ACTTC). EF1 and GADPH were chosen based on their ubiquitous and constitutive expression pattern in P. margaritifera tissue.

A 10-fold dilution series was created from a random pool of cDNA from our samples (including $C, F A$ and $H A$ phenotypes), ranging from $\times 100$ dilutions to $\times 100,000 \mathrm{di}-$ lutions. Triplicate RT- $q$ PCR reactions were carried out as described above for each gene at each dilution. Mean cycle threshold $(\mathrm{C} t)$ values for each dilution were plotted against the $\log 10$ of the cDNA input for each gene to generate efficiency plots. The reaction efficiency of each gene assay was calculated using the following equation: $\mathrm{E}=$ $10(-1 /$ slope $)$ where $\mathrm{E}$ is the reaction efficiency and 'slope' is the slope of the line generated in the efficiency plots. Only the genes yielding an efficiency comprised between $90 \%$ and $110 \%$ were retained.

\section{RT- $q$ PCR data analysis}

The $C t$ values of the replicates for each housekeeping gene and each candidate gene of each phenotype $(C, F A$ and $H A$ pooled or individual samples) were reported. For each candidate gene, the level of transcription was normalized using the following calculation:

$$
\Delta \mathrm{Ct}=\mathrm{C} t_{\text {Target }}-\mathrm{C} t_{\mathrm{M}}
$$

where $C t_{\text {Target }}$ is the mean $C t$ of the target gene in one of the tested phenotype $(C, F A$ and $H A$ pooled or individual samples) and $C t_{M}$ is the mean $C t$ of the housekeeping genes in that same phenotype.

Relative quantification of gene expressions was estimated for each gene in each phenotype using the $\Delta \Delta C t$ method as described in [59]. Relative quantification relates the PCR signal of the target transcript (here $F A$ or $H A$ phenotypes) in a treatment group to that of another sample (here $C$ phenotype). We used the following equation:

$$
\Delta \Delta C t=\Delta C t_{\text {Target }}-\Delta C t_{\mathrm{C}}
$$

where $\Delta C t_{\text {Target }}$ is the $\Delta C t$ obtained for a target gene in one of the tested phenotype ( $F A$ and $H A$ pooled or individual samples) and $\Delta C t_{C}$ is the $\Delta C t$ obtained for that same gene in the phenotype $C$. In the pooled analysis $\Delta \mathrm{C} t_{\mathrm{C}}$ is the $\Delta \mathrm{C} t$ of the pooled $C$ individuals whereas in the individual analysis the $\Delta C t_{C}$ is the mean $\Delta C t$ obtained for each individual from the $C$ phenotype.

Finally the relative expression fold for each gene in each tested condition in relation to the phenotype $C$ was estimated using the following equation:

$$
\mathrm{E}^{*} 2^{-(\Delta \Delta C t)}
$$

where $\mathrm{E}$ is the reaction efficiency for each target gene.

For each target gene in each tested phenotype of the pooled analysis, a relative expression fold superior to 2 was considered as significantly differentially expressed $[60,61]$. For the individual analysis, significances among mean relative expression folds of each gene were determined by an analysis of variance (ANOVA).

\section{Results}

\section{Subtractive cDNA library construction and sequencing}

Two SSH libraries were produced to identify differentially expressed genes between normally black colored and full albinos specimens of Pinctada margaritifera. Nine hundred and sixty (960) clones were sequenced from each library, yielding 677 and 580 high quality cDNA sequences (>100 bp), after removing low-quality regions and screening for vector contamination, from the $C$ and $F A$ libraries respectively. The ESTs from the $C$ library generated 120 contigs and 238 singletons (358 total analyzed sequences after discarding redundant sequences), indicating that the overall redundancy of the library was $18 \%$. The ESTs from 
Table 1 Characteristics of the genes selected for the pooled and individual RT-qPCR analyses. The proteins, primers and efficiencies values are indicated. The genes selected for the individual analysis are indicated in bold

\begin{tabular}{|c|c|c|c|c|}
\hline Gene code & Protein & Primers & Efficiencies \% & Genbank accession \# \\
\hline KRMP & Lysine $(\mathrm{K})$-rich mantle protein & Joubert et al. 2014 & 95 & JZ845792 \\
\hline \multirow[t]{2}{*}{ SHEM $9 B$} & \multirow[t]{2}{*}{ Shematrin 9} & A_shem9b 5'- F CCCCGTATCCTCCATATCC & \multirow[t]{2}{*}{101} & \multirow[t]{2}{*}{ JZ845577 } \\
\hline & & A_shem9b 3'- R GCTATTACCGGAGTACCCTACG & & \\
\hline \multirow[t]{2}{*}{ SHEM 1B } & \multirow[t]{2}{*}{ Shematrin 1} & C_Shem1b F 5'- CGCTATCGTTGCTCTCATTG & \multirow[t]{2}{*}{101.00} & \multirow[t]{2}{*}{ JZ845578 } \\
\hline & & C_Shem1b R 3'- TCCACCTCCTCCTCCTCTTC & & \\
\hline \multirow[t]{2}{*}{ TYR $2 A$} & \multirow[t]{2}{*}{ Tyrosinase 2} & A_tyr2a F 5'- GCGGCTCTACTGTCAAATGG & \multirow[t]{2}{*}{112.00} & \multirow[t]{2}{*}{ JZ845579 } \\
\hline & & A_tyr2b R 3'- CTGGACCTTTCAGGGACTGG & & \\
\hline \multirow[t]{2}{*}{ TYR 2C } & \multirow[t]{2}{*}{ Tyrosinase 2} & A tyr2c F 5'- CCCGTGGCCTGGATAGTC & \multirow[t]{2}{*}{101.00} & \multirow[t]{2}{*}{ JZ845580 } \\
\hline & & A tyr2C R 3'- TITTCTTCCATCACTGCTACATTG & & \\
\hline \multirow[t]{2}{*}{ FLAV } & \multirow[t]{2}{*}{ Flavonol cinnamoyl CoA reductase-related } & A_flav aF 5'- AGCAGGGTTATCACGTCAGG & \multirow[t]{2}{*}{96.00} & \multirow[t]{2}{*}{$J Z 845581$} \\
\hline & & A_flav bR 3'- ATCCTTTGGTGCCTGTGC & & \\
\hline \multirow[t]{2}{*}{ METH } & \multirow[t]{2}{*}{ Methionine-rich nacre protein } & A_Meth bF 5'- ATGCGGAGGATACTGTGCTT & \multirow[t]{2}{*}{100.00} & \multirow[t]{2}{*}{ JZ845582 } \\
\hline & & A_Meth bR 3'- CGGGGCTGGATAGACTCATA & & \\
\hline \multirow[t]{2}{*}{ CLP3 } & Chitinase 3 protein & A_clp3b F 5'- TCACAAAATGGATCATAACGTACC & 94.00 & JZ845583 \\
\hline & & A_clp3b R 3'- GGACTGCCTTTGAATGTCG & & \\
\hline$P D Z$ & PDZ domain protein & A_PDZa F 5'- TGAGCTTCAGAGAGGTGACG & 100.00 & $J Z 845584$ \\
\hline & & A_PDZa R 3'- AACATTTGGTGAGGGTTTGG & & \\
\hline MP10 & Mantle protein 10 & A_MP10d F 5'-ATTATGGACCGGGCAAGC & 100.00 & $J Z 845585$ \\
\hline & & A_MP10c R 3'- GAGGACAGGAACATCAACAGG & & \\
\hline EGF & Epidermal growth factor receptor & A_EGF aF 5'- CATTCCCCATCTTCCTCAAA & 108.00 & JZ845586 \\
\hline & & A-EGF aR 3'- GGACTTCCTGGGATGTTGTC & & \\
\hline PHOS & Phosphotyrosine protein phosphatase & A_Phos bF 5'- AATTATGACACAGAGGGATCTAAGG & 98.00 & JZ845587 \\
\hline & & A_Phos aR 3'- CATAGAAACCACCACAACATCG & & \\
\hline YTH & YTH domain family protein 2-like & A_YTH aF 5'- AATTGAGACACATTCGGTTGG & 93.00 & JZ845588 \\
\hline & & A_YTH aR 3'- TTACCGCTCTCTGTCCTTGC & & \\
\hline PIF & Pif177-like protein & A_pif aF 5'- TITTGAATTACACGACTGCTTG & 93.00 & JZ845589 \\
\hline & & A_pif aR 3'- TTCAGTAGAACTAACGCTAAATCCAG & & \\
\hline CHIT & Chitin synthase & A_Chit aF 5'- AATCCAATTTCCCGCAGTC & 90.00 & $J Z 845590$ \\
\hline & & A_Chit bR 3'- TTGTTGTAGACATTAGCGACGTATC & & \\
\hline YBOX & Y-box binding protein & A_Ybox aF 5'- CGTACATCAAACTGCCATTACC & 97.00 & JZ845591 \\
\hline & & A_Ybox aR 3'- CTACATCAAATTCCACCTTCTCC & & \\
\hline COLL & Collagen alpha-1 (XI) chain precursor & A_Coll bF 5'- CGTCCAATCAATCCAGGTG & 105.00 & $J Z 845592$ \\
\hline & & A_Coll aR 3'- TGGGTCCAAAAGGTGAAATG & & \\
\hline GIGA & Gigasin & A_Giga aF 5'- TCTCTTCCGGTCAAAAATGC & 91.00 & JZ845593 \\
\hline & & A_Giga aR 3'- TCGCTGTACTATTTCCGTTCG & & \\
\hline SHEM 4 & Shematrin 4 & A_Shem4a F 5'- GCTTCCCATCGGTTTATGG & 92.00 & JZ845594 \\
\hline & & A_Shem4b 3'- R TGCCAACATTTCCGTATCC & & \\
\hline CAL & Calreticulin & A_Cal aF 5'- TCACCATCCATTTCATCATCC & 102.00 & JZ845595 \\
\hline & & A_Cal aR 3'- ACCAGAGGACTGGGACAAGC & & \\
\hline PEROX & Peroxidase & A_Perox aF 5'- TGCTGGGACTCACTCTATCCA & 107.00 & JZ845596 \\
\hline & & A_Perox bR 3'- TCAAGCCATCAAAGAAACATCTT & & \\
\hline MP8 & Mantle protein 8 & Joubert et al. 2014 & 101.00 & JZ845791 \\
\hline ASP & Aspein shell matrix protein & Joubert et al. 2014 & 99.00 & $J Z 845790$ \\
\hline
\end{tabular}


Table 1 Characteristics of the genes selected for the pooled and individual RT-qPCR analyses. The proteins, primers and efficiencies values are indicated. The genes selected for the individual analysis are indicated in bold (Continued)

\begin{tabular}{|c|c|c|c|c|}
\hline \multirow[t]{2}{*}{ MAT } & \multirow[t]{2}{*}{ Matrilin Cartilage matrix protein } & A_Mat aF 5'- TTGTTCTGGATGGGTCTTCG & \multirow[t]{2}{*}{109.00} & \multirow[t]{2}{*}{ JZ845597 } \\
\hline & & A_Mat aR 3'- TCAAAGCCCGCACATCAG & & \\
\hline \multirow[t]{2}{*}{ SHEM 8} & \multirow[t]{2}{*}{ Shematrin 8} & C_Shem8 bF 5'- CTCCACCACCAATGACGATT & \multirow[t]{2}{*}{111.00} & \multirow[t]{2}{*}{ JZ845598 } \\
\hline & & C_Shem8 aR 3'- TITCGGGGGTGTTAACGTAG & & \\
\hline \multirow[t]{2}{*}{ FER } & \multirow[t]{2}{*}{ Ferritin } & C_Fer CF 5'- GGGCCTGATTGACAGACTTCT & \multirow[t]{2}{*}{96.00} & \multirow[t]{2}{*}{ JZ845599 } \\
\hline & & C_Fer CR 3'- GAGGGCGCATTGTCCTTC & & \\
\hline \multirow[t]{2}{*}{ PERL } & \multirow[t]{2}{*}{ Perlin matrix protein } & C_Perl bF 5'- TTCCAGATATTACACCCTGTGCT & \multirow[t]{2}{*}{100.00} & \multirow[t]{2}{*}{ JZ84560C } \\
\hline & & C_Perl aR 3'-CGTTACCGTTTCCACCAAAA & & \\
\hline \multirow[t]{2}{*}{ PRISM } & \multirow[t]{2}{*}{ Prism uncharacterized shell protein } & C_Prism aF 5'- TGGTTCCAAGTGTATTTGTCCA & \multirow[t]{2}{*}{96.00} & \multirow[t]{2}{*}{ JZ845601 } \\
\hline & & C_Prism aR 3'- TCCATAGACGCACACCTTTG & & \\
\hline \multirow[t]{2}{*}{ MP88 } & \multirow[t]{2}{*}{ molluscan prismatic and nacreous layer 88} & C_MP88a F 5'- TCTGTGAAAATITTGATAAACTGAA & \multirow[t]{2}{*}{109.00} & \multirow[t]{2}{*}{ JZ845602 } \\
\hline & & C_MP88a R 3'- GAATAAAAGTTTAATGTTCCATTCCT & & \\
\hline \multirow[t]{2}{*}{ CHK1 } & \multirow[t]{2}{*}{ Checkpoint-like protein } & C_CHK1a F 5'- CGGGCAGGTACTCATTCC & \multirow[t]{2}{*}{95.00} & \multirow[t]{2}{*}{$J Z 845603$} \\
\hline & & C_CHK1b R 3'- GCTACCACATCCAAGGAAGG & & \\
\hline \multirow[t]{2}{*}{ LAMIN } & \multirow[t]{2}{*}{ Laminin receptor precursor } & C_Lamin bF 5'- GAAGCTGAGAAAGAAGAACAGACC & \multirow[t]{2}{*}{101.00} & \multirow[t]{2}{*}{ JZ845604 } \\
\hline & & C_Lamin aR 3'- TGTTGTGGTGGCTGTATTGC & & \\
\hline \multirow[t]{2}{*}{ SEST } & Sestrin 1-like protein & C_Sest aF 5'- TाTाTGCTACCAGGACTTGC & 91.00 & JZ845605 \\
\hline & & C_Sest aR 3'- GTGTCAACATCTGTCATCTCACC & & \\
\hline FIBRO & Fibronectin 3 & C_Fibro aF 5'- AGTAGCTGATCGTGCATTCG & 97.00 & JZ845606 \\
\hline & & C_Fibro bR 3'- AACTCACAGGACACCAAAACG & & \\
\hline SHELL & Nacre uncharacterize shell protein 6 & C_Shell_CF 5'-CGTTCTATCCCTGGTCATCC & 101.00 & JZ845607 \\
\hline & & C_Shell_dR 3'- GGACGTGGATTTCCTTGG & & \\
\hline SERP & Serine protease inhibitor & C_SerP_CF 5'- AGGTGTGTACCATTCTTCTACGG & 92.00 & JZ845608 \\
\hline & & C_SerP_CR 3'- GCAAACATCTCCTCCATCTCC & & \\
\hline ZINC & Zinc metalloprotease & C_Zinc bF 5'-CAGAGATGGTTITGTGTTACTTACG & 105.00 & JZ845609 \\
\hline & & C_Zinc aR 3'- GCTTTGAGGCATTCATGTCC & & \\
\hline TRANS & Translocon-associated protein subunit & C_Trans aF 5'- TGCCCTAAAGAGGGAAAGC & 102.00 & $J Z 845610$ \\
\hline & & C_Trans aR 3'- CCACAATTAGCAGCACAAGG & & \\
\hline
\end{tabular}

the $F A$ library generated 82 contigs and 264 singletons (346 total analyzed sequences after discarding redundant sequences), indicating $54 \%$ redundancy of this library. The average length of the ESTs was $521 \mathrm{bp}$ and $781 \mathrm{bp}$ in the $C$ and $F A$ libraries, respectively (Table 2).

Singletons and consensus clusters were subjected to BLATX searches in UniProt; $58 \%$ of all the blasted sequences from the $C$ library and $59 \%$ from the $F A$ library obtained a sequence description. Most of the sequences of known gene function presented similarities to predicted proteins from unknown species (records that have no known mapping to the NCBI taxonomy) and $P$. margaritifera.

The 358 sequences obtained from the $C$ library and the 346 sequences issued from the $F A$ library were separately annotated and classified according to the terms of the main Gene Ontology vocabulary for molecular function level 3, using the Blast2GO software. $18.9 \%$ of the ESTs from the $C$ library were related to the structural constituent of ribosome category (See Additional file 1). In both libraries, a large number of categories were attributed to binding (57\% and $66 \%$ of the ESTs from the $C$ and $F A$ libraries respectively, Figs. 2 and 3); which includes protein and ion binding, organic cyclic and heterocyclic compound binding, transcription factor and DNA binding (Figs. 2 and 3). Overall, 23 categories of genes were solely found in the $F A$ library, including functions such as transcription factor activity, extracellular matrix binding or metalloenzyme regulator activity (Fig. 3 and Additional file 2).

\section{Confirmation of differentially expressed genes by RT- $q$ PCR}

Quantitative real-time PCR experiments were carried out to validate gene differential expressions and to search for differential expression among the black $(C)$, 
Table 2 General characteristics of the black $(C)$ and Full Albino (FA) SSH libraries

\begin{tabular}{lll}
\hline & $C$ & $F A$ \\
\hline Sequenced clones & 960 & 960 \\
Retained sequences & 677 & 580 \\
Analyzed cDNA & 358 & 346 \\
Mean EST size (bp) & 521 & 781 \\
Contigs & 120 & 82 \\
EST in contigs & 439 & 316 \\
Singletons & 238 & 264 \\
Redundancy (\%) & 18 & 54 \\
\hline
\end{tabular}

full albino $(F A)$ and half albino $(H A)$ phenotypes. Thirty seven genes (37) associated with aragonite formation, periostracum and calcite biosynthesis, shell protein matrix formation, melanin biosynthesis, ion binding, oxidase activity and transcription factors were selected to perform the expression analyses on the pooled individuals (Table 1).

The RT- $q$ PCR performed on the pooled individual in each of the three phenotypes revealed that four genes were found to be significantly up-regulated in the $F A$ phenotype (SHEM 1, PEROX, SERP and ZINC) and two in the $H A$ phenotype (KRMP and $S E R P)$ relatively to the $C$ phenotype (one being shared with the $F A$ phenotype; Fig. 4). The expression of eight other genes was downregulated in the $F A$ and $H A$ phenotypes (SHEM 9, PDZ,
PIF, COLL, SHEM 4, MP8, ASP and PRISM). In addition, the expression of 2 more genes were down-regulated in the $H A$ phenotype (FLAV, ZINC) relatively to the $C$ phenotype. Within the five up-regulated genes in the $F A$ and $H A$ phenotypes, two are known to play a role in the shell calcitic layer biosynthesis (SHEM 1 and KRMP) and one is known to be involved in the shell nacreous layer biosynthesis (SERP). Of the 10 down-regulated genes found in the $F A$ and $H A$ phenotypes, four are known to play a role in the shell calcitic layer biosynthesis (SHEM 9, SHEM 4, PRISM and FLAV) and one is known to be involved in the shell nacreous layer biosynthesis (PIF). The gene ZINC, involved in melanin biosynthesis, was oppositely expressed in the two albino condition: up-regulated in the $F A$ condition and downregulated in the $H A$ condition (Fig. 4).

Once the previous results were compiled, 9 genes were finally selected for the subsequent individual RT- $q$ PCR analysis based on their high differential expression level and their known or predicted role at different levels of the shell formation: SHEM 1, SHEM 4, PDZ, PIF, MP8, PRISM, SERP, ZINC and KRMP. In addition and although they did not show significant differential expression in the pooled analysis, two more genes, CHIT and TYR $2 a$, were included in the individual RT- $q$ PCR analysis because of their known role in melanin biosynthesis. Some genes showing differential expression patterns in the pooled analysis were however not included in the individual RT- $q$ PCR analysis because they

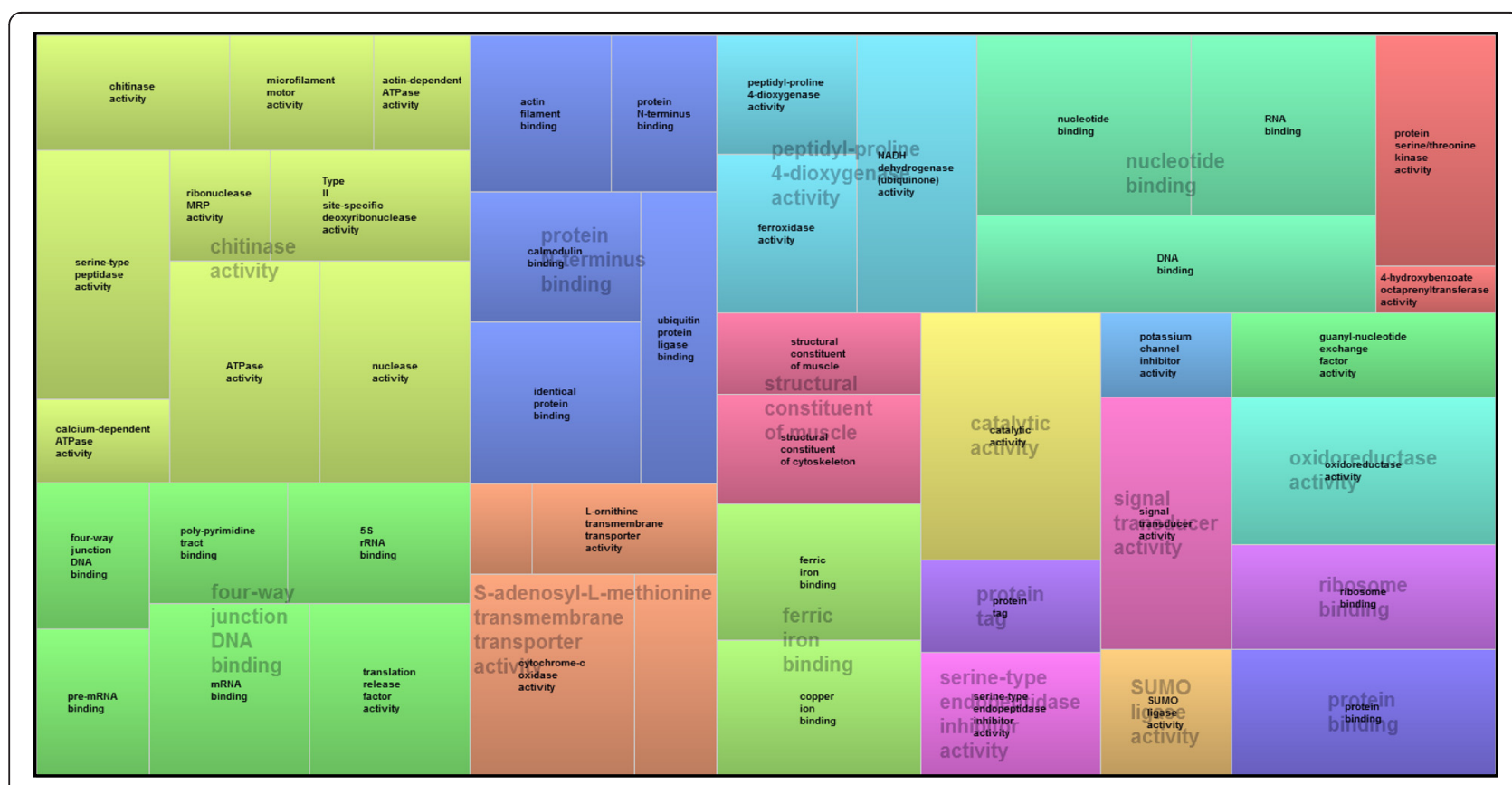

Fig. 2 TreeMap visualization of the summary of GO Molecular function found for the black phenotypes, obtained with a Revigo analysis. The size of each boxe is correlated to the frequencies of the occurence of the GO-term. Boxes with the same color are grouped by semantic similarity (SimRel, similarity $=0.7$ ) and correspond to the same upper-hierarchy GO-term which is found in grey in the middle of each box 


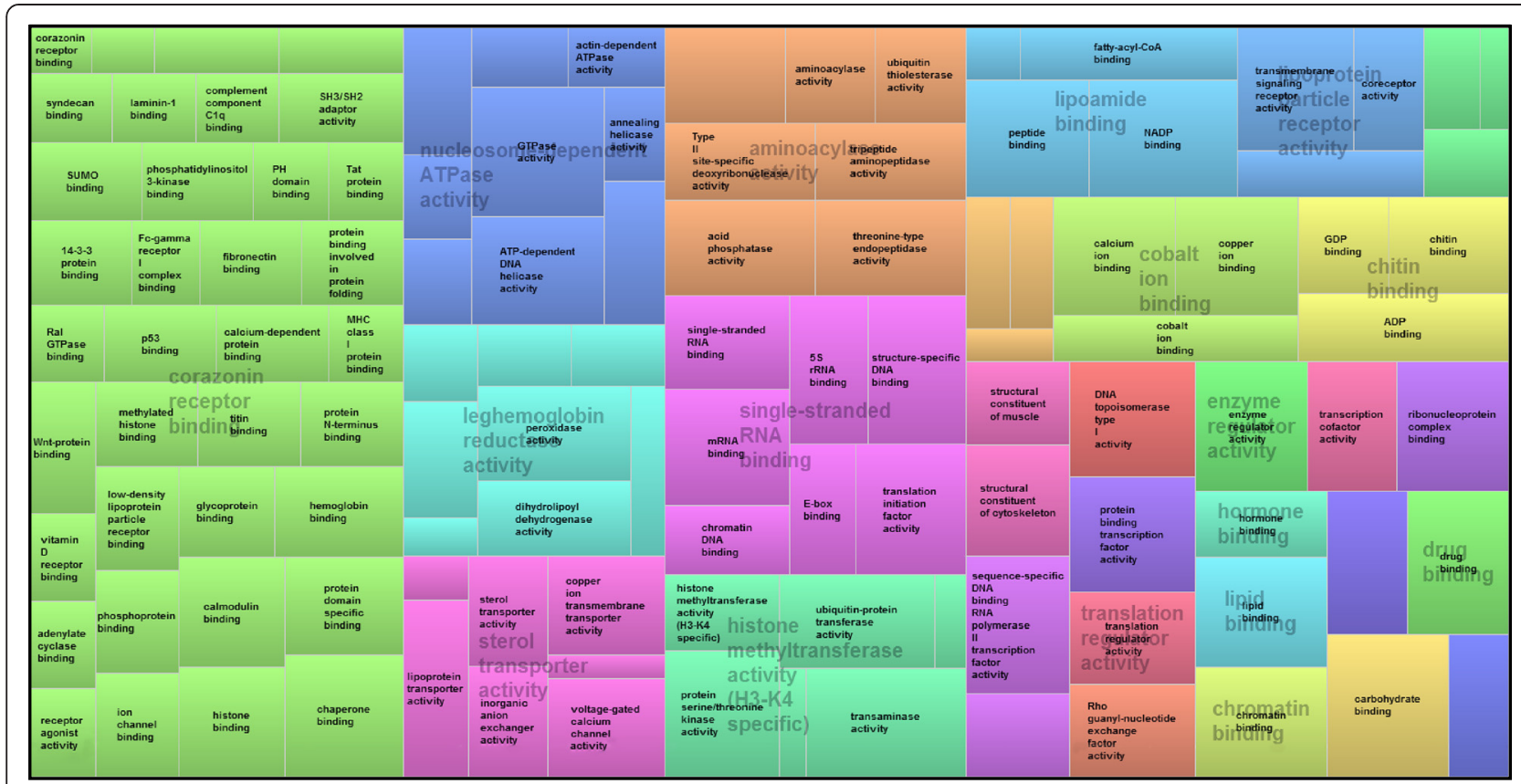

Fig. 3 TreeMap visualization of the summary of GO Molecular function found for the full albinos phenotypes obtained with a Revigo analysis. The size of each boxe is correlated to the frequencies of the occurence of the GO-term. Boxes with the same color are grouped by semantic similarity (SimRel, similarity $=0.7$ ) and correspond to the same upper-hierarchy GO-term which is found in grey in the middle of each box

belonged to the same sub-family and showed similar expression pattern as another gene selected for this analysis, e.g. SHEM 9, COLL or ASP. The genes SHEM 9 and SHEM 4 displayed the same expression pattern and are part of the same shematrin sub-family; as a consequence we choose to analyze only SHEM 4 and SHEM 1 which both belong to two different shematrin subfamilies. The same reasoning was applied to the gene COLL that is supposed to have a similar role as the gene CHIT. In addition we tried to select a somewhat equal number of genes involved in the different shell layers (calcitic and aragonite) and in pigmentation, thus excluding the gene $A S P$, involved in the calcitic layer formation and for which we already had selected 4 genes. The RT-qPCR performed on each individual of each phenotype separately, revealed the same expression patterns as the pooled analysis for most genes. The gene SHEM 1 displayed a different expression pattern than the one obtained from the pooled analysis: i.e. absence of differential expression in any tested conditions. The genes SHEM 4, MP8, SERP and KRMP failed to display differentially significant expression patterns among phenotypes because of high individual variability in the expression of those genes in the $C$ phenotype (which we used as a reference value, Fig. 5). In fact, individual RT$q \mathrm{PCR}$ analyses revealed that the relative expression of most targeted genes in the $C$ phenotype significantly differed from 1 (except for SHEM 1, TYR 2a, PIF and ZINC). This result highlights the high amount of inter- individual gene expression variability in the black specimens ( 1 being the value corresponding to an absence of variation).

\section{Discussion}

The nacreous layer of the Polynesian black-lipped pearl oyster Pinctada margaritifera exhibits a large array of color variation among individuals. In order to study the corresponding molecular mechanisms behind the nacre color variation patterns, a selection of genes differentially expressed between normal black specimens of pearl oyster and two types of albinos were identified using a SSH method and characterized. A subset of these genes encode for proteins involved in shell formation and in the melanin biosynthesis chain.

\section{Origin of shell color induced by shell matrix protein expressed in the nacre and calcitic layers}

The genes PIF and COLL, directly involved in biomineralization of the nacreous layer, both showed higher expression in the black phenotype compared to both albino phenotypes in all RT-qPCR analyses for PIF and in the pooled analysis for COLL. PIF codes for the gene PmargPif, previously identified by [21]. It is a homolog to Pif-177 found in Pinctada fucata [62] and is known to specifically bind to aragonite crystals. Pif-177 is an important component of the nacreous layer and takes part in the initiation of aragonite crystallization as well as subsequent stacking of aragonite tablets in the nacreous layer. Pif- 177 also 


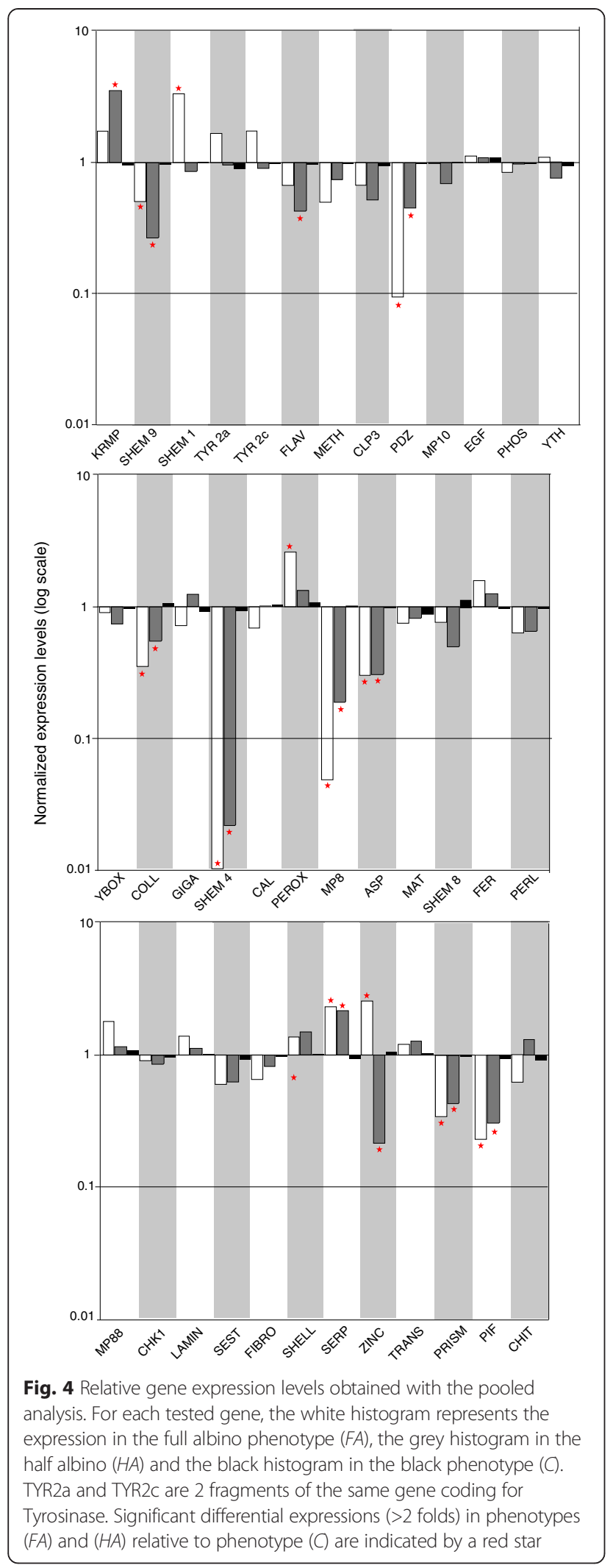

takes part in lamellar sheet formation and therefore it is an essential component of the organic matrix for normal growth of the nacreous layer [62]. Berland [24] showed that the down-regulation of the gene coding for Pif- 177 led to a cessation of growth of the nacreous layer. The gene COLL (coding for Collagen alpha-1 XI chain precursor) is involved in the growth of collagen II fibrils in humans and seems to be related to chitin in bivalves [63]. Here, we show that both PIF and COLL are most likely involved in the establishment of color in the shell of $P$. margaritifera. Because the proteins produced by these genes are specifically expressed in the organic matrix and regulate the orientation of the $\mathrm{c}$ axis of the aragonite crystals $[62,64]$, we hypothesize that the color glints observed in the nacre are entailed to the orientation of the aragonite crystals. We however encourage conducting in situ hybridization experiments in the near future to confirm this hypothesis. The weak expression of these genes in the albino phenotypes suggests that the arrangement of albino aragonite crystals differs from those of black shells and contribute to a colorless nacre.

Differential expression patterns were however not detected for all genes involved in nacre formation. The genes coding for the proteins chitin and pearlin showed low expression in the albino phenotypes but this differential expression was not significant $(0.6$ instead of $<0.5$ for under expression). Chitin is a polysaccharide widely distributed in living organisms and is considered to be a fundamental template in biomineralization, as an alternative to collagen [63]. In bivalves, chitin is involved in shell matrix scaffolding. It is the core of the organic framework surrounding the aragonite tablets in the nacreous layer [64]. Pearlin is also known to play a direct role in the formation of the aragonite crystals in $P$. maragaritifera [12, 65-68]. The fact that these two proteins deeply involved in nacre formation are not showing differential expression patterns among phenotypes tends to indicate that the nacre is not the predominant shell layer responsible for the color of the shell of $P$. margaritifera. However, this conclusion has to be regarded with caution as there are many more genes involved in the formation of the nacreous layer that were not explored in the present work and that could display differential expression. In addition, other processes such as posttranscriptional mRNA treatments were not taken into account here. The different expression patterns observed for COLL and CHIT also suggest that the two amplified fragments code for two distinct proteins playing a different role in the biomineralization process.

On the other hand, our analyses detected differential expression of many genes known to be involved in the formation of the calcitic layer of $P$. margaritifera, suggesting that variation in shell color could primarily take place in the calcitic layer. These genes code for organic 


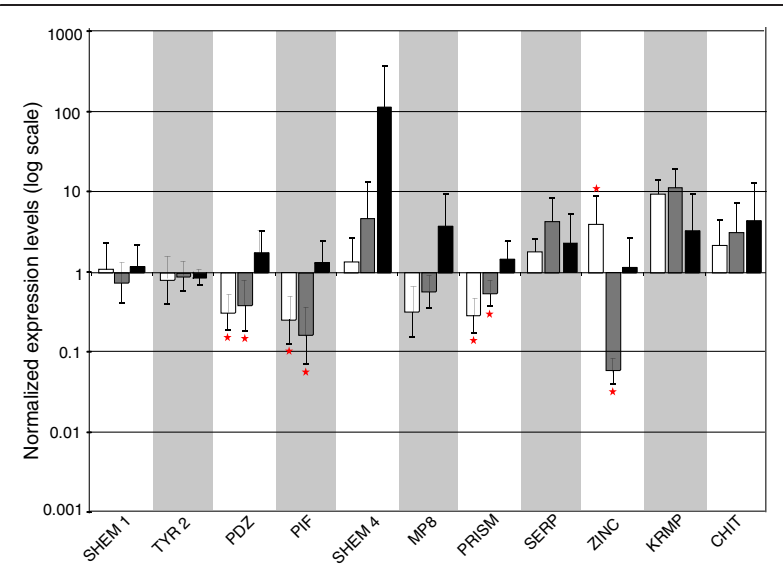

Fig. 5 Relative gene expression levels obtained with the individual analysis. For each tested gene, the white histogram represents the expression in the full albino phenotype ( $F A)$, the grey histogram in the half albino $(H A)$ and the black histogram in the black phenotype (C). Significant differential expressions in phenotypes (FA) and $(H A)$ relative to phenotype $(C)$ (determined by an ANOVA) are indicated by a red star

matrix proteins produced in the mantle and were found to be highly expressed in the black specimens. Proteins produced in the mantle are secreted into the extrapallial space, where calcium carbonate $\left(\mathrm{CaCO}_{3}\right)$ crystallizes to build unusual microstructures [69]. The mechanism of this process is unknown, but may involve interactions of the matrix proteins and inorganic ions present in the extrapallial space, leading to crystallization of $\mathrm{CaCO}_{3}$ and morphogenesis of the species-specific appearance of the shell [69]. Here, we detected high expressions of two genes in the black phenotype, PRISM and MP8, coding for recently discovered proteins: uncharacterized shell matrix protein 18 and mantle protein 8 , both believed to be involved in the formation of the calcitic layer ( $B$. Marin, pers. comm.). Three more genes, homologs of genes found in P. fucata and coding for proteins of the shematrin family, SHEM 4 and SHEM 9, and a gene coding for Aspein (ASP) also showed high expression patterns in the black phenotypes in the pooled analysis. Shematrin proteins form a family of mollusk proteins exclusively expressed in the mantle, and particularly in the edge region of the mantle $[69,20]$. Recent findings suggest that shematrin proteins are synthesized in the mantle edge and secreted into the prismatic layer of the shell, where they are thought to provide a framework for calcification and to be responsible for the toughness of the shell [69]. Aspein is an acidic protein that has a sequence rich in aspartic acid and is expressed at the outer edge of the mantle [70]. It is the shell matrix protein that controls the precipitation of calcite in P. fucata and it is the most acidic protein found in molluscan shell matrix protein [71]. The opposite pattern was observed for two genes coding for proteins participating in the formation of the calcitic layer: KRMP and SHEM 1. The two genes were found to be highly expressed in both albino phenotypes compared to the black phenotype, in the pooled analysis. SHEM 1 codes for another homolog of the shematrin family: shematrin-1, which was classified as belonging to a different sub-group of shematrins, along with shematrin-2 and -3 in P. fucata [69]. These differences imply that they may play a different role in the formation of the calcitic layer and could explain the opposite expression pattern observed for SHEM 1 compared to SHEM 4 and SHEM 9 in $P$. margaritifera. KRMP stands for lysine (K)-rich matrix protein and codes for a matrix protein family participating in the framework formation of the prismatic layer [72].

The high expression of PRISM, MP8, SHEM 4, SHEM 9, and ASP and the weak expression of SHEM 1and $K R M P$ in the black phenotypes suggests that the origin of color in the nacre is under the influence of genes directly involved in biomineralization of the calcitic layer. The two opposite expression patterns observed between genes highlights the complexity of this genetic process.

\section{Role of pigments in the origin of shell color}

A gene not directly linked to the calcification process, ZINC displayed a significantly higher expression pattern in full albino $(F A)$ phenotypes compared to half albino $(H A)$ and black phenotypes $(C)$. ZINC stands for a gene coding for a protein with a metallic zinc ion binding and catalytic domain: Zinc metalloprotease. This gene is a homolog of Tyrosinase related protein 1 [73] which is known to be involved in the melanin biosynthesis pathway: a tyrosinase-like protein detected in the periostracum layer of P. fucata by [52] and named OT47. Tyrosinases are considered to be involved in many biological activities of mollusks, including native immune response [74, 75], formation of egg capsules [76-78], byssus $[76,79,80]$, shell matrix proteins $[76,81,82]$, and periostracum $[76,83]$. OT47 was found to be expressed in the middle fold of the mantle edge of $P$. fucata supporting the assumption that it contributes to the periostracum development. The periostracum is an uncalcified layer covering the outer surface of mollusk shell. It is among the strongest mechanically and the most chemically inert structures in the animal kingdom [76]. In addition to the directly protective contribution to the organism, the periostracum is also thought to play a significant role in shell biomineralization [84]. The periostracum encloses the extrapallial space on the ventral side and isolates it from the external environment, enabling the formation of supersaturation conditions, which is a requisite for the formation of calcified layers [85, 86]. Previous studies also showed that it could serve as a substrate for the initial deposition of calcium and even influence the prismatic layer formation [84, 85, 87-89]. 
Albino phenotypes are supposed to be mainly the result of the absence of melanin biosynthesis or of synthesis of non- or partly functional melanin protein $[44,90]$. The high expression of ZINC in the full albino phenotype compared to normal black and half albino phenotypes suggests that the full albino phenotype might overcompensate for a nonfunctional melanin protein by over-expressing the gene coding for this protein. Finally, FLAV (coding for Flavonol Cinnamoyl COA reductase related) was found to be highly expressed in the black phenotypes, in the pooled analysis. Flavonol Cinnamoyl COA reductase is an enzyme that contributes in the phenylpropanoid biosyntheis in plants and is enhanced for acclimatization processes at different levels of photosynthetic photon flux [91-94]. Mutations in the gene coding for flavonols in angiosperms have shown to induce dramatic color changes in the flower organs [95]. The gene we detected in P. magaritifera is related to the gene coding for this enzyme and although no information is available about its role in animals, we can hypothesize that a homologous function to acclimatization to various levels of light can be found in P. margaritifera as the over-expression of this gene is correlated with the presence of a black mantle (which translates into melanin pigment biosynthesis in these individuals).

The expression patterns of genes involved both in the biomineralization of the periostracum and the synthesis of melanin suggest once again that the origin and polymorphism of the color in the nacre of $P$. margaritifera takes place in all the layers of the shell and in different biological processes.

\section{Differential expression of genes not directly involved in biomineralization processes}

Two genes coding for proteins involved in metabolic processes showed significant differential expression among phenotypes: SERP and PDZ. The gene SERP coding for Serine protease inhibitor or serpins (which is part of a large family of enzymes that inhibit the activity of proteases) showed high expression levels in both albino conditions, in the pooled analysis. A limited number of serpins proteins has been reported in bivalves or mollusks and so far they are thought to be involved in an immune defensive role against invasive pathogens $[94,96]$. The gene coding for a PDZ domain protein (PDZ) showed significantly higher expression levels in black phenotypes than in albino phenotypes, both in the pooled and individual analyses. PDZ domains are one of the most frequently encountered domains, consisting of approximately 90 amino acid residues and identified as a region of sequence homology among a diverse list of signaling proteins [97, 98]. The reason why these genes exhibit differential expression patterns across phenotypes remains unclear and will need further explorations.

\section{Inter-individual variability in gene expression within black phenotypes}

One major outcome of the individual analysis performed on 11 genes is the existence of high gene expression variability within the black phenotypes for most of the genes tested and mostly for SHEM 4, MP8, KRMP, CHIT and SERP, characterized by high standard deviation values and gene expression levels different than 1 (1 being the value corresponding to an absence of variation; Fig. 5). It is well known that what is commonly named as the black-lipped pearl oyster is in fact a pool of a wide range of shell colors varying from several shades of yellows, reds, greens and blues. The black specimens used in this study as a control phenotype for the individual analysis, were selected randomly. The inter-individual gene expression variation detected within those samples highlights the diversity of colors found in our pool of black phenotypes. This result supports the hypothesis that SHEM 4, MP8, KRMP, CHIT and SERP are very likely to be involved not only in the origin of shell color but also in the variability of the shell color among "black" specimens. The presence of these wide variations in expression patterns in the black phenotypes, used as controls in this analysis, could also be responsible for preventing the detection of significant differential expression patterns in the individual analyses of albinos specimens when those patterns were significant in the pooled analysis.

\section{Conclusions}

The goal of this study was to identify a subset of genes involved in the color of the nacreous layer of the pearl oyster Pinctada margaritifera, and assess their expression discrepancies. The role of the proteins encoded by the genes showing differential expression levels among the different tested phenotypes revealed that three main genetic processes were involved in color polymorphisms: the biomineralization of the nacreous and calcitic layers and the synthesis of pigments such as melanin in the periostracum. However, our results suggest that the color observed in the nacre is mainly under the influence of genes involved in the biomineralization of the calcitic layer. A few genes involved in the formation of the aragonite tablets of the nacre and in the biosynthesis chain of melanin also showed differential expression patterns, suggesting that color polymorphism takes place at different levels in the shell structure. Color in various organisms like birds or flowers is known to be under the influence of a combination of genes coding for multiple pigments (melanin and carotenoid being the most commons in birds and anthocyanin in angiosperms) and surface structure [99, 95]. Different gene expression arrangements seem to lead to the extraordinary variety of colors and iridescence observed in 
bird feathers and flower organs $[99,95]$. Similarly, it appears that the genes involved in the origin and variation of color in the Polynesian black-lipped pearl oyster span a large range of functions from shell structure to pigment synthesis. Future studies, using RNA-Seq technology and in situ hybridization analyses of the genes identified in the present work will help define more precisely the role of the different shell layers in the origin of the color of the nacre. The high variability of the gene expression found within black phenotypes furthermore suggests that the present work should serve as a basis for future studies exploring more thoroughly the expression patterns of candidate genes within black phenotypes with different dominant iridescent colors.

\section{Availability of supporting data}

The datasets supporting the results of this article are included within the article and its additional files.

\section{Additional files}

Additional file 1: Pie chart visualization of the summary of GO Molecular function level 3 found for the black phenotypes, obtained with the Blast2GO software. (PDF $4 \mathrm{~kb}$ )

Additional file 2: Pie chart visualization of the summary of GO Molecular function level 3 found for the full albinos phenotypes, obtained with the Blast2GO software. (PDF $7 \mathrm{~kb}$ )

\section{Abbreviations}

ANOVA: Analysis of variance; $\mathrm{C}$ : Colored phenotype; $\mathrm{CaCO}_{3}$ : Calcium carbonate; Ct: Cycle threshold; E: Efficiency; EST: Expressed sequence tag; FA: Full albino phenotype; HA: Half albino phenotype; SSH: Suppressive and subtractive hybridization.

\section{Competing interests}

The authors declare that they have no competing interests.

\section{Authors' contribution}

SL designed and carried out the molecular genetic studies and experiments in the laboratory, analyzed the data and wrote the manuscript. DL, SL and YG helped conceive and design the experiments. SP participated in its design and coordination and helped to draft the manuscript. All authors read and approved the final manuscript.

\section{Acknowledgements}

We thank all 'ADEQUA' collaborators and Cedrik Lo in particular for the helpful information on pearl culture industry in French Polynesia. We would like to thank Pascal Ung for providing and dissecting albino specimens. We are grateful to Caroline Joubert for her help with the RT-qPCR analyses. We thank Gonzalo Giribet for editing the English of the manuscript. We acknowledge Rx. Bioscience Ldt (Maryland, USA) for constructing the SSH libraries. Two anonymous reviewers provided constructive comments and helped improve this paper. This research was supported by the Service de la Perliculture, the Groupement de Recherche "ADEQUA", Proscience, REGENPERL of French Polynesia, PolyPerl and Biodiperl (French National Research agency).

\section{Author details}

'Laboratoire d'Excellence "CORAIL", USR 3278 CNRS-CRIOBE- EPHE, Perpignan, France, Papetoai, Moorea, French Polynesia. ${ }^{2}$ Present address: Department of Organismic and Evolutionary Biology, Museum of Comparative Zoology, Harvard University, 26 Oxford Street, Cambridge, MA 02138, USA. ${ }^{3}$ Ifremer, UMR 241 ElO, Laboratoire d'Excellence "CORAIL", BP 7004, 98719 Taravao,
Tahiti, French Polynesia. ${ }^{4}$ Present address: Ifremer, UMR 5244 IHPE, UPVD, CNRS, Université de Montpellier, CC 80, F-34095 Montpellier, France.

Received: 6 December 2014 Accepted: 14 July 2015

Published online: 01 August 2015

\section{References}

1. Liu X, Wu F, Zhao H, Zang G, Guo X. A novel shell color variant of the Pacific abalone Haliotis discus hannai Ino subject to genetic control and dietary influence. J Shellfish Res. 2009;28:419-24.

2. Canales-Gómez E, Correa G, Viana MT. Effect of commercial carotene pigments (astaxanthin, cantaxanthin and $\beta$-carotene) in juvenile abalone Haliotis rufescens diets on the color of the shell or nacre. Vet Mexico. 2010;41:191-200.

3. David Jl, Leslie EH. Inheritance of a shell-color polymorphism in the mussel. J Hered. 1977;68:203-4

4. Kraeuter J, Adamkewicz L, Castagna M, Wall R, Karney R. Rib number and shell color in hybridized subspecies of the Atlantic bay scallop, Argopecten irradians. Nautilus. 1984:98:17-20.

5. Adamkewicz L, Castagna M. Genetics of shell color and pattern in the bay scallop Argopecten irradians. J Hered. 1988;79:14-7.

6. Palmer AR. Genetic basis of shell variation in Thais emarginata (Prosobranchia, Muricacea). I. Banding in populations from Vancouver Island. Bio Bull. 1985;169:638-51.

7. Ekendahl A, Johannesson K. Shell colour variation in Littorina saxatilis Olivi (Prosobranchia: Littorinidae): a multi-factor approach. Bio J Linn Soc Lond. 1997:62:401-19.

8. Yusa Y. Inheritance of colour polymorphism and the pattern of sperm competition in the apple snail Pomacea canaliculata (Gastropoda: Ampullariidae). J Molluscan Stud. 2004;70:43-8.

9. Peignon JM, Gerard A, Naciri Y, Ledu C, Phelipot P. Analysis of the shell color determinism in the Manila clam Ruditapes philippinarum. Aquat Living Resour. 1995:8:181-9.

10. Winkler FM, Estevez BF, Jollan LB, Garrido JP. Inheritance of the general shell color in the scallop Argopecten purpuratus (Bivalvia : Pectinidae). J Hered. 2001;92:521-5.

11. Wen H, Gu R, Cao Z, Zhou X, Nie Z, Ge X, et al. Variation of color and ray pattern in juvenile shells in hatchery-produced freshwater triangle pearl mussels, Hyriopsis cumingii, in China. J World Aquac Soc. 2013;44:154-60.

12. Samata T, Hayashi N, Kono M, Hasegawa K, Horita C, Akera S. A new matrix protein family related to the nacreous layer formation of Pinctada fucata. FEBS Lett. 1999;462:225-9.

13. Weiss IM, Kaufmann S, Mann K, Fritz M. Purification and Characterization of Perlucin and Perlustrin, Two New Proteins from the Shell of the Mollusc Haliotis laevigata. Biochem Biophys Res Commun. 2000;267:17-21.

14. Suzuki M, Murayamae E, Inoue H, Ozaki N, Tohse H, Kogure T, et al. Characterization of Prismalin-14, a novelmatrix protein from the prismatic layer of the Japanese pearl oyster, Pinctada fucata. Biochem J. 2004;382:205-13.

15. Zhang $C$, Li S, Ma Z, Xie L, Zhang R. A novel matrix protein p10 from the nacre of pearl oyster (Pinctada fucata) and its effects on both $\mathrm{CaCO} 3$ crystal formation and mineralogenic cells. Mar Biotechnol (NY). 2006;8:624-33.

16. Marie B, Marie A, Jackson DJ, Dubost L, Degnan BM, Milet $C$, et al. Proteomic analysis of the organic matrix of the abalone Haliotis asinina calcified shell. Proteome Sci. 2010;8:54

17. Marie B, Zanella-Cléon I, Roy L, Becchi M, Luquet G, Marin F. Proteomic analysis of the acid-soluble nacre matrix of the bivalve Unio pictorum: Detection of Novel Carbonic Anhydrase and Putative Protease Inhibitor Proteins. ChemBioChem. 2010;11:2138-47.

18. Marie B, Le Roy N, Zanella-Cléon I, Becchi M, Marin F. Molecular evolution of mollusc shell proteins: insights from proteomic analysis of the edible mussel Mytilus. J Mol Evol. 2011;72:531-46.

19. Marie B, Trinkler N, Zanella-Cléon I, Guichard N, Becchi M, Paillard C, et al. Proteomic identification of novel proteins from the calcifying shell matrix of the Manila clam Venerupis philippinarum. Mar Biotechnol (NY). 2011;13:955-62.

20. Marie B, Joubert C, Belliard C, Tayale A, Zanella-Cléon I, Marin F, et al. Characterization of MRNP34, a novel methionine-rich nacre protein from the pearl oysters. Amino Acids. 2012;42:2009-17. 
21. Joubert C, Piquemal D, Marie B, Manchon L, Pierrat F, Zanella-Cleon I, et al. Transcriptome and proteome analysis of Pinctada margaritifera calcifying mantle and shell: focus on biomineralization. BMC Genomics. 2010;11:613.

22. Miyashita T, Hanashita T, Toriyama M, Takagi R, Akashika T, Higashikubo N. Gene cloning and biochemical characterization of the BMP-2 of Pinctada fucata. Biosci Biotechnol Biochem. 2008;72:37-47.

23. Wang A, Wang Y, Gu Z, Li S, Shi Y, Guo X. Development of expressed sequence tags from the pearl oyster, Pinctada martensii Dunker. Marine Biotechnol. 2011;13:275-83.

24. Berland S, Marie A, Duplat D, Milet C, Sire JY, Bédouet L. Coupling proteomics and transcriptomics for the identification of novel and variant forms of mollusk shell proteins: a study with P. margaritifera. ChemBioChem. 2011;12:950-61.

25. Gardner LD, Milss D, Wiegand A, Leavesley D, Elizur A. Spatial analysis of biomineralization associated gene expression from the mantle organ of the pearl oyster Pinctada maxima. BMC Genomics. 2011;12:455.

26. Shi Y, Yu C, Gu Z, Zhan X, Wang Y, Wang A. Characterization of the pearl oyster (Pinctada martensii) mantle transcriptome unravels biomineralization genes. Mar Biotechnol. 2013;15:175-87.

27. Liu Y, Shigley JE, Hurwit KN. Iridescence color of a shell of the mollusk Pinctada margaritifera caused by diffraction. Opt Express. 1999;4:177-82.

28. Tan T, Wong D, Lee P. Iridescence of a shell of mollusk Haliotis glabra. Opt Express. 2004;12:4847-54

29. Snow MR, Pring A, Self P, Losic D, Shapter J. The origin of pearls in iridescence from nano-composite structures of the nacre. Am Mineral. 2004;89:1353-8.

30. Takahashi K, Yamamoto H, Onoda A, Doi M, Inaba T, Chiba M, et al. Highly oriented aragonite nanocrystal-biopolymer composites in an aragonite brick of the nacreous layer of Pinctada fucata. Chem Commun. 2004;996-997.

31. Nudelman F, Shimoni E, Klein E, Rousseau M, Bourrat X, Lopez E, et al. Forming nacreous layer of the shells of the bivalves Atrina rigida and Pinctada margaritifera: An environmental- and cryo-scanning electron microscopy study. J Struct Biol. 2008;162:290-300.

32. Farre B, Brunelle A, Laprévote O, Cuif JP, Williams CT, Dauphin Y. Shell layers of the black-lip pearl oyster Pinctada margaritifera: matching microstructures and composition. Comp Biochem Physiol B Biochem Mol Biol. 2011;159:131-9.

33. Raman C. On iridescent shells. Part II. Colours of laminar diffraction. Proc Indian Acad Sci. 1935;A1:574-89.

34. Webster R, Anderson BW. Gems, their sources, descriptions and identification. London: Buterworths; 1983.

35. Marin F, Luquet $G$, Marie $B$, Medakovic D. Molluscan shell proteins: primary structure, origin, and evolution. Curr Top Dev Biol. 2007;80:209-76.

36. Kinoshita S, Wang N, Inoue H, Maeyama K, Okamoto K, Nagai K, et al. Deep sequencing of ESTs from nacreous and prismatic layer producing tissues and a screen for novel shell formation-related genes in the pearl oyster. PLoS One. 2011;6, e21238.

37. Marie B, Joubert C, Tayalé A, Zanella-Cléon I, Belliard C, Piquemal D, et al. Different secretory repertoires control the biomineralization processes of prism and nacre deposition of the pearl oyster shell. Proc Natl Acad Sci U S A. 2012:109:20986-91.

38. Belcher AM, Wu X, Christensen R, Hansma P, Stucky G, Morse D. Control of crystal phase switching and orientation by soluble mollusc-shell proteins. Nature. 1996;381:56-8.

39. Falini G, Albeck S, Weiner S, Addadi L. Control of aragonite or calcite polymorphism by mollusk shell macromolecules. Science. 1996;271:67-9.

40. Addadi L, Weiner S. Interactions between acidic proteins and crystals: stereochemical requirements in biomineralization. Proc Natl Acad Sci U S A. 1985;82:4110-4.

41. Weiner S, Hood L. Soluble protein of the organic matrix of mollusk shells: a potential template for shell formation. Science. 1975;190:987-9.

42. Le Pennec M, Anastas M, Bichet H, Buestel D, Cochard J, Cochennec Laureau N, et al. Huître Perlière et Perle de Tahiti. French Polynesia: Faaa; 2010. p. 204.

43. Bassi MT, Schiaffino MV, Renieri A, Denigris F, Galli L, Bruttini M, et al. Cloning of the gene for ocular albinism type 1 from the distal short arm of the X chromosome. Nat Genet. 1995;10:13-9.

44. King RA, Summers CG. Albinism. Dermatol Clin. 1988;6:217-28.

45. Tomita Y, Takeda A, Okinaga S, Tagami H, Shibahara S. Human oculocutaneous albinism caused by single base insertion in the tyrosinase gene. Biochem Biophys Res Commun. 1989;164:990-6.
46. Nakamura K, Ozaki A, Akutsu T, Iwai K, Sakamoto T, Yoshizaki G, et al. Genetic mapping of the dominant albino locus in rainbow trout (Oncorhynchus mykiss). Mol Genet Genomics. 2001;265:687-93.

47. King RA, Willaert RK, Schmidt RM, Pietsch J, Savage S, Brott MJ, et al. MC1R mutations modify the classic phenotype of oculocutaneous albinism type 2 (OCA2). Am J Hum Genet. 2003;73:638-45

48. Boissy RE, Zhao HQ, Oetting WS, Austin LM, Wildenberg SC, Boissy YL, et al. Mutation in and lack of expression of tyrosinase-related protein-1 (TRP-1) in melanocytes from an individual with brown oculocutaneous albinism: A new subtype of albinism classified as "OCA3". Am J Hum Genet. 1996;58:1145-56

49. Newton JM, Cohen-Barak O, Hagiwara N, Gardner JM, Davisson MT, King RA, et al. Mutations in the human orthologue of the mouse underwhite gene (uw) underlie a new form of oculocutaneous albinism, OCA4. Am J Hum Genet. 2001;69:981-8.

50. Fox DL, Hochachka PW. Biochromy of the Mollusca. In: Saleudin ASM, Wilbur KM, editors. The Mollusca. Volume 2. New York: Academic; 1983. p. 281-303.

51. Jabbour-Zahab R, Chagot D, Blanc F, Grizel H. Mantle histology, histochemistry and ultrastructure of the pearl oyster pinctada margaritifera (L.). Aquat Living Res. 1992;5:287-98,

52. Zhang C, Xie LP, Huang J, Chen L, Zhang RQ. A novel putative tyrosinase involved in periostracum formation from the pearl oyster (Pinctada fucata). Biochem Biophys Res Commun. 2006;342:632-9.

53. Nagai $\mathrm{K}$, Yano M, Morimoto K, Miyamoto $\mathrm{H}$. Tyrosinase localization in mollusc shells. Comp Comp Biochem Physiol B Biochem Mol Biol. 2007;146:207-14

54. Diatchenko L, Lukyanov S, Lau YFC, Siebert PD. Suppression subtractive hybridization: A versatile method for identifying differentially expressed genes. Methods Enzymol. 1999:303:349-80.

55. Rebrikov DV, Britanova OV, Gurskaya NG, Lukyanov KA, Tarabykin VS, Lukyanov SA. Mirror orientation selection (MOS): a method for eliminating false positive clones from libraries generated by suppression subtractive hybridization. Nucleic Acids Res. 2000;28:e90.

56. Supek F, Bošnjak M, Škunca N, Šmuc T. REVIGO summarizes and visualizes long lists of gene ontology terms. PLoS One. 2011;6, e21800.

57. Joubert C, Linard C, Le Moullac G, Soyez C, Saulnier D, Teaniniuraitemoana $V$, et al. Temperature and food influence shell growth and mantle gene expression of shell matrix proteins in the pearl oyster Pinctada margaritifera. PLoS One. 2014;9, e103944.

58. Larsen JB, Frischer ME, Rasmussen LJ, Hansen BW. Single-step nested multiplex PCR to differentiate between various bivalve larvae. Mar Biol. 2005;146:1119-29.

59. Livak KJ, Schmittgen TD. Analysis of relative gene expression data using real-time quantitative PCR and the $2^{\Delta \Delta C T}$ method. Methods. 2001;25:402-8.

60. Wang W, Yang L, Suwa T, Casson PR, Hornsby PJ. Differentially expressed genes in zona reticularis cells of the human adrenal cortex. Mol Cell Endocrinol. 2001;173:127-34.

61. Larkin P. Expression profiling of estrogenic compounds using a sheepshead minnow CDNA macroarray. Environ Health Perspect. 2003;111:83962.

62. Suzuki M, Saruwatari K, Kogure T, Yamamoto Y, Nishimura T, Kato T, et al. An acidic matrix protein, Pif, is a key macromolecule for nacre formation. Science. 2009:325:1388-90.

63. Ehrlich $\mathrm{H}$. Chitin and collagen as universal and alternative templates in biomineralization. Int Geol Rev. 2010;52:661-99.

64. Suzuki M, Nagasawa $\mathrm{H}$. The structure-function relationship analysis of Prismalin-14 from the prismatic layer of the Japanese pearl oyster, Pinctada fucata. FEBS J. 2007;274:5158-66.

65. Miyashita T, Takagi R, Okushima M, Nakano S, Miyamoto H, Nishikawa E, et al. Complementary DNA cloning and characterization of pearlin, a new class of matrix protein in the nacreous layer of oyster pearls. Mar Biotechnol. 2000;2:409-18.

66. Yan ZG, Jing G, Gong NP, Li CZ, Zhou YJ, Xie LP, et al. N40, a novel nonacidic matrix protein from pearl oyster nacre, facilitates nucleation of aragonite in vitro. Biomacromolecules. 2007;8:3597-601.

67. Kono M, Hayashi N, Samata T. Molecular mechanism of the nacreous layer formation in Pinctada maxima. Biochem Biophys Res Commun. 2000;269:213-8.

68. Montagnani C, Marie B, Marin F, Beliard C, Riquet F, Tayalé A, et al. Pmarg-Pearlin is a matrix protein involved in nacre framework formation in the pearl oyster Pinctada margaritifera. Chembiochem. 2011;12:2033-43. 
69. Yano M, Nagai K, Morimoto K, Miyamoto $H$. Shematrin: A family of glycine-rich structural proteins in the shell of the pearl oyster Pinctada fucata. Comp Biochem Physiol B Biochem Mol Biol. 2006;144:254-62.

70. Takeuchi T, Endo K. Biphasic and dually coordinated expression of the genes encoding major shell matrix proteins in the pearl oyster Pinctada fucata. Mar Biotechnol. 2005:8:52-61.

71. Tsukamoto D, Sarashina I, Endo K. Structure and expression of an unusually acidic matrix protein of pearl oyster shells. Biochem Biophys Res Commun. 2004;320:1175-80.

72. Zhang C, Xie L, Huang J, Liu X, Zhang R. A novel matrix protein family participating in the prismatic layer framework formation of pearl oyster, Pinctada fucata. Biochem Biophys Res Commun. 2006;344:735-40.

73. Theos AC, Truschel ST, Raposo G, Marks MS. The Silver locus product Pmel17/gp100/Silv/ME20: controversial in name and in function. Pigment Cell Res. 2005;18:322-36.

74. Asokan R, Arumugam M, Mullainadhan P. Activation of prophenoloxidase in the plasma and haemocytes of the marine mussel Perna viridis Linnaeus. Dev Comp Immunol. 1997;21:1-12.

75. Cong R, Sun W, Liu G, Fan T, Meng X, Yang L, et al. Purification and characterization of phenoloxidase from clam Ruditapes philippinarum. Fish Shellfish Immunol. 2005;18:61-70.

76. Waite JH. Quinone-tanned scleroproteins. In: Saleudin ASM, Wilbur KM, editors. The Mollusca. Volume 4. New York: Academic; 1983. p. 467-504

77. Hunt S. Comparison of three extracellular structural proteins in the gastropod mollusc Buccinum undatum L., the periostracum, egg capsule and operculum. Comp Biochem Physiol B: Comp Biochem. 1971;40:37-40.

78. Bai G, Brown JF, Watson C, Yoshino TP. Isolation and Characterization of Phenoloxidase from Egg Masses of the Gastropod Mollusc, Biomphalaria glabrata. Comp Biochem Physiol B: Comp Biochem. 1997;118:463-9.

79. Brown C. Some structural proteins of Mytilus edulis. Q J Microsc Sci. 1952:3:487-502.

80. Waite J, Tanzer M. The bioadhesive of Mytilus byssus: a protein containing L-dopa. Biochem Biophys Res Commun. 1980;96:1554-61.

81. Degens ET, Spencer DW, Parker RH. Paleobiochemistry of molluscan shell proteins. Comp Biochem Physiol. 1967;20:553-79.

82. Gordon J, Carriker M. Sclerotized protein in the shell matrix of a bivalve mollusc. Mar Biol. 1980;57:251-60.

83. Waite JH, Wilbur KM. Phenoloxidase in the periostracum of the marine bivalve Modiolus demissus Dillwyn. J Exp Zool. 1976;195:359-67.

84. Checa AG, Salas C, Harper EM, Bueno-Pérez JD. Early stage biomineralization in the periostracum of the 'living fossil' bivalve Neotrigonia. PLoS One. 2014;9:e90033.

85. Saleuddin ASM, Petit HP, Wilbur KM. The mode of formation and the structure of the periostracum. In: Saleudin ASM, Wilbur KM, editors. The Mollusca. Volume 4. New York: Academic; 1983. p. 199-234.

86. Wilbur K, Saleuddin A. Shell formation. In: Saleudin ASM, Wilbur KM, editors. The Mollusca. Volume 4. New York: Academic; 1983. p. 235-87.

87. Wada K. Electron microscopic observations of the formation of the periostracum of Pinctada fucata. Bull Nat Pearl Res Lab. 1968;13:1540-60.

88. Petit H, Davis WL, Jones RG, Hagler H. Morphological studies on the calcification process in the fresh-water mussel Amblema. Tissue Cell. 1980;12:13-28.

89. Checa A. A new model for periostracum and shell formation in Unionidae (Bivalvia, Mollusca). Tissue Cell. 2000;32:405-16.

90. Oetting WS, King RA. Molecular basis of albinism: Mutations and polymorphisms of pigmentation genes associated with albinism. Hum Mut. 1999;13:99-115.

91. Flint SD, Jordan PW, Caldwell MM. Plant protective response to enhanced UV-B radiation under field conditions: leaf optical properties and photosynthesis. Photochem Photobiol. 1985;41:95-9.

92. Harborne JB, Williams CA. Advances in flavonoid research since 1992. Phytochem. 2000;55:481-504.

93. Middleton EM, Teramura AH. Understanding photosynthesis, pigment and growth responses induced by UV-B and UV-A irradiances. Photochemi Photobiol. 1994;60:38-45.

94. Iwanaga S, Lee BL. Recent advances in the innate immunity of invertebrate animals. BMB Rep. 2005;38:128-50.

95. Quattrocchio F, Wing J, van der Woude K, Souer E, de Vetten N, Mol J, et al. Molecular analysis of the anthocyanin2 gene of Petunia and its role in the evolution of flower color. Plant Cell. 1999;11:1433-44.
96. Nikapitiya C, De Zoysa M, Oh C, Lee Y, Ekanayake PM, Whang I, et al. Disk abalone (Haliotis discus discus) expresses a novel antistasin-like serine protease inhibitor: Molecular cloning and immune response against bacterial infection. Fish Shellfish Immunol. 2010;28:661-71.

97. Ponting CP. Evidence for PDZ domains in bacteria, yeast, and plants. Prot Sci. 1997:6:464-8.

98. Ponting CP, Phillips C, Davies KE, Blake DJ. PDZ Domains: Targeting signalling molecules to sub-membranous sites. BioEssays. 1997;19:469-79.

99. Ralf LC. The control of color in Birds. Am Zool. 1969;9:521-30.

\section{Submit your next manuscript to BioMed Central and take full advantage of:}

- Convenient online submission

- Thorough peer review

- No space constraints or color figure charges

- Immediate publication on acceptance

- Inclusion in PubMed, CAS, Scopus and Google Scholar

- Research which is freely available for redistribution 